\title{
PROBLEMATIKA WAKAF ASET TANAH PERSYARIKATAN MUHAMMADIYAH DI SULAWESI SELATAN
}

\author{
Oleh. Ambo Rappe \\ Pasca Sarjana STAIN Watampone \\ Email : amborappe90@gmail.com
}

\begin{abstract}
This study concerns the problem of Muhammadiyah waqf land assets in the province of South Sulawesi. The first problem is how to manage waqf land in Muhammadiyah organizations in South Sulawesi. Second, what efforts have been made in resolving the problem of Muhammadiyah waqf land assets in South Sulawesi.

The type of research used is field research conducted at all Muhammadiyah Regional Leadership Offices in South Sulawesi province. Data was collected through interviews, collections, and observations. This study concludes that; First, the management of waqf land assets is still traditional, which is intended only for development activities and social activities. In fact, management has not run optimally. Therefore, it still needs cooperation between the Waqf Board and the Property with other parties in the management of waqf land assets so that they can run effectively and benefit. Second, the land assets are less pronounced and not aimed at the economic empowerment that only oriented to the devotional activities.
\end{abstract}

Keywords: Waqf; Land Asset; Muhammadiyah.

\begin{abstract}
Abstrak
Penelitian ini membahas masalah aset tanah wakaf Muhammadiyah di provinsi Sulawesi Selatan. Pertama, bagaimana pengelolaan tanah wakaf pada organisasi Muhammadiyah di Sulawesi Selatan. Kedua, upaya apa yang telah dilakukan dalam menyelesaikan masalah aset tanah wakaf Muhammadiyah di Sulawesi Selatan.

Jenis penelitian yang digunakan adalah penelitian lapangan yang berlokasi di seluruh Kantor Pimpinan Daerah Muhammadiyah di provinsi Sulawesi Selatan. Data dikumpulkan melalui wawancara, dokumentasi, dan observasi. Penelitian ini menyimpulkan bahwa; Pertama, pengelolaan aset tanah wakaf masih tradisional, yang dimaksudkan hanya untuk kegiatan pembangunan dan kegiatan sosial. Padahal, manajemen belum berjalan optimal. Oleh karena itu, masih dibutuhkan kerja sama antara Dewan Wakaf dan pihak lain dalam pengelolaan wakaf aset tanah sehingga mereka dapat berjalan secara efektif dan bermanfaat. Kedua, aset tanah kurang jelas dan tidak ditujukan pada pemberdayaan ekonomi yang hanya berorientasi pada kegiatan Sosial.
\end{abstract}

Kata kunci: Wakaf; Aset Tanah; Muhammadiyah. 


\section{A. Pendahuluan}

Bagi masyarakat Indonesia yang mayoritas penduduknya beragama Islam, wakaf merupakan salah satu ibadah yang cukup direspon oleh mereka. Praktek wakaf yang terjadi dalam kehidupan masyarakat belum sepenuhnya berjalan tertib dan efisien, sehingga dalam berbagai kasus harta benda wakaf tidak terpelihara sebagaimana mestinya, terlantar atau beralih ke tangan pihak ketiga dengan cara melawan hukum. Keadaan demikian itu, tidak hanya karena kelalaian atau ketidakmampuan nāzi ir dalam mengelola dan mengembangkan harta benda wakaf, tetapi karena juga sikap masyarakat yang kurang peduli atau belum memahami status harta benda wakaf yang seharusnya dilindungi demi untuk kesejahteraan umum sesuai dengan tujuan, fungsi, dan peruntukan wakaf. ${ }^{1}$

Dalam Undang-undang No. 41 Tahun 2004 Pasal 1 Undang-Undang No.41 Tahun 2004 Tentang Wakaf, disebutkan bahwa:

"Wakaf adalah perbuatan hukum wakif untuk memisahkan dan/atau menyerahkan sebahagian harta benda miliknya untuk dimanfaatkan selamanya atau jangka waktu tertentu sesuai dengan kepentingannya guna keperluan ibadah dan/atau kesejahteraan umum menurut syari'ah".

Lembaga wakaf adalah salah satu bentuk perwujudan keadilan sosial dalam Islam. Prinsip kepemilikan harta dalam ajaran Islam, bahwa harta tidak dibenarkan hanya dikuasai oleh sekelompok orang atau individu semata. Harta tidak hanya dinikmati sendiri, melainkan harus dinikmati bersama. Bukan berarti Islam melarang orang untuk menjadi kaya raya, melainkan suatu peringatan kepada umat manusia bahwa Islam mengajarkan fungsi sosial harta. ${ }^{2}$

Sebagai suatu lembaga Islam, wakaf telah menjadi salah satu penunjang perkembangan masyarakat Islam. Salah satu bentuk wakaf yang banyak dilaksanakan di Indonesia adalah dalam bentuk tanah. Kebiasaan berwakaf sebenarnya telah berkembang sedemikian rupa di kalangan umat Islam di Indonesia, walaupun hasilnya belum maksimal seperti yang diharapkan.

\footnotetext{
${ }^{1}$ Rachmadi Usman, Hukum Perwakafan Di Indonesia. Cet. 1; Jakarta : Sinar Grafika, 2009, h. 121

2 Juhaya S Praja, Perwakafan di Indonesia:Sejarah, Pemikiran, Hukum dan Perkembangannya. Cet. 1; Bandung:Yayasan Tiara, 1995, h.1
} 
Kenyataan ini memerlukan penanganan profesional untuk mengembangkan potensi wakaf sebagai penunjang dakwah Islamiyah. ${ }^{3}$

Selama ini peruntukan wakaf di Indonesia kurang mengarah pada pemberdayaan ekonomi umat dan cenderung hanya kepentingan kegiatan-kegiatan ibadah, karena pada umumnya memahami bahwa peruntukan wakaf hanya terbatas untuk kepentingan peribadatan dan hal-hal yang lazim dilaksanakan di Indonesia seperti untuk masjid, mushalla, sekolah, makam dan lain-lain. Perwakafan selama ini, belum diatur secara tuntas dalam peraturan perundangundangan yang ada. Wakaf mengalir begitu saja seperti apa adanya, kurang memperoleh penanganan yang sungguh-sungguh, baik ditinjau dari pemberian motivasi maupun pengelolaannya. Akibatnya dapat dirasakan hingga kini, yaitu terjadi penyimpangan pengelolaan wakaf dari tujuan wakaf sesungguhnya.

Keadaan demikian tidak selaras dengan maksud dari wakaf yang sesungguhnya dan juga akan mengakibatkan kesan kurang baik terhadap Islam sebagai akses penyelewengan wakaf. Tidak jarang sengketa wakaf terpaksa harus diselesaikan di pengadilan, padahal kalau dikaji dengan seksama, perkembangan Islam di Indonesia tidak dapat dilepaskan dari adanya peranan wakaf. Artinya, jumlah harta wakaf khususnya wakaf tanah belum mencukupi dan berpengaruh secara signifikan di masyarakat. Di samping sebagai salah satu aspek ajaran Islam yang berdimensi spiritual, wakaf juga merupakan ajaran yang menekankan pentingnya kesejahteraan ekonomi (dimensi sosial). ${ }^{4}$

Salah satu yang menjadi tindakan wakaf adalah peranannya dalam pemerataan kesejahteraan di kalangan umat dan penanggulangan kemiskinan. Juga berfungsi mewujudkan potensi ekonomi harta benda wakaf untuk kepentingan ibadah dan untuk memajukan kesejahteraan umum. Namun wakaf yang sejatinya demikian dalam perakteknya masih menyimpan problematika dan berbagai persoalan. Fenomena ini bukan hanya muncul dalam masyarakat di

\footnotetext{
${ }^{3}$ Abdul Ghofur Anshori, Hukum dan Praktik Perwakafan di Indonesia, Yogyakarta: Pilar Media, 2005, h. 2

${ }^{4}$ Kementerian Agama RI, "Paradigma Baru Wakaf di Indonesia. Jakarta: Direktorat Pemberdayaan Wakaf Direktorat Jenderal Bimbingan Masyarakat Islam, 2006, h.1
} 
Indonesia saja, tetapi juga di negara-negara lain dalam berbagai periode sejarah umat Islam. 5

Persoalan dan tantangan terhadap harta tanah wakaf yang tidak dilengkapi dengan sertifikat adalah sangat rawan bagi timbulnya persengketaan, bahkan dapat menyebabkan hilangnya aset kekayaan harta benda wakaf. Di organisasi kemasyarakatan seperti Muhammadiyah masih banyak persoalan perwakafan tanah yang belum terselesaikan. Dalam penelitian ini penulis melakukan observasi lapangan terkait seputar "Problematika Wakaf Aset Tanah Muhammadiyah di Sulawesi Selatan.

Keadaan demikian itu tidak selaras dengan maksud dari wakaf yang sesungguhnya dan juga akan mengakibatkan kesan kurang baik terhadap Islam sebagai akses penyelewengan wakaf. Tidak jarang sengketa wakaf terpaksa harus diselesaikan di pengadilan, padahal kalau dikaji dengan seksama, perkembangan Islam di Indonesia tidak dapat dilepaskan dari adanya peranan wakaf. Artinya, jumlah harta wakaf khususnya wakaf tanah belum mencukupi dan berpengaruh secara signifikan di masyarakat.

Melihat fenomena itu, pemerintah merasa berkewajiban untuk menata dalam rangka meminimalisir dampak negatif akibat kurang jelasnya status wakaf, terutama wakaf dalam bentuk tanah. Untuk wakaf tanah penataannya dimulai oleh pemerintah, antara lain melalui Undang-undang No. 5 Tahun 1960 tentang Peraturan Dasar Pokok-Pokok Agraria yaitu Pasal 49 mengenai hak-hak tanah untuk keperluan suci dan sosial dan beberapa peraturan pelaksanaannya, seperti Peraturan Pemerintah No.10 Tahun 1960, tentang Pendaftaran Tanah, Peraturan Pemerintah tentang penunjukan badan-badan hukum yang dapat mempunyai hak milik atas tanah (PP No. 38 Tahun 1963), Peraturan Menteri Agraria No. 14 Tahun 1961 tentang Pedoman-Pedoman Pokok Penyelenggaraan Pendaftaran Tanah sebagaimana diatur dalam PP No. 10 tahun $196 .^{6}$

\footnotetext{
${ }^{5}$ Satria Efendi M Zein, "Saksi dan Ikrar Dalam Wakaf", dalam Problematika Hukum Keluarga Islam Kontemporer Cet. 1; Jakarta: Fakultas Syari'ah dan Hukum UIN Jakarta dan Balitbang DEPAG RI, 2004, h. 409-410

${ }^{6}$ Muhammad Daud Ali, Sistem Perekonomian Islam, Zakat dan Wakaf, Cet. I; Jakarta: UIPress, 1988, h. 101
} 
Menyadari arti pentingnya tanah wakaf itu, maka pemerintah merasa perlu untuk memberikan dasar hukum yang lebih kuat bagi pelaksanaan perwakafan tanah milik tersebut, demi menunjang kehidupan beragama dalam masyarakat. Oleh karena itu disusun dan dikeluarkan Peraturan Pemerintah No.28 Tahun 1977 tentang Perwakafan Tanah Milik, dan Inpres Nomor 1 Tahun1991 tentang Kompilasi Hukum Islam (KHI) mengenai Hukum Perwakafan serta UndangUndang Nomor 41 Tahun 2004 tentang Wakaf dan Peraturan Pemerintah Nomor 42 Tahun 2006 tentang Pelaksanaan Undang-Undang Nomor 41 Tahun 2004 tentang Wakaf, yang di dalamnya ada kekhususan yaitu mengenai wakaf tunai yang merupakan hal baru dalam perwakafan di Indonesia. ${ }^{7}$

Penulis menemukan adanya persoalan perwakafan, khususnya aset tanah Persyarikatan Muhammadiyah yang terdapat pada beberapa daerah Kabupaten/Kota di Sulawesi Selatan. Permasalahan yang dihadapi oleh Persyarikatan Muhammadiyah yang mempunyai jumlah harta kekayaan (aset) berupa tanah yakni; tanah hak milik 185 lokasi dengan luas $\tau_{+} 4.524 .594 \mathrm{~m}^{2}$, tanah wakaf 158 lokasi dengan luas $2.875 .306 \mathrm{~m}^{2}$ dan tanah hak pakai 6 lokasi dengan luas $12.000 \mathrm{~m}^{2}$. Dari sekian banyak aset dimaksud, belum semua kekayaannya tercatat dengan baik disemua jenjang Persyarikatan dan amal usahanya, yakni atas nama Persyarikatan sebagaimana diatur dalam undangundang keormasan itu sendiri.

Selain itu masih terdapat pula lokasi yang belum dikelola secara maksimal dan diorientasikan kepada pemberdayaan harta wakaf produktif. Permasalahan berikutnya adalah masih munculnya sikap ahli waris wakif yang menarik kembali tanah wakaf yang telah diwakafkan oleh wakif, protes ahli waris wakif terhadap tanah yang telah diwakafkan oleh wakif dengan maksud ingin memiliki tanah tersebut kembali. Permasalahan perwakafan yang menarik juga adalah kondisinya yang kurang berkembang. Perwakafan ini terjadi di tengah-tengah umat Islam yang mempunyai tingkat wawasan ilmu agama dan hukum Islam yang cukup tinggi. Kondisi tersebut idealnya mampu menciptakan suasana yang cukup

\footnotetext{
${ }^{7}$ Abdul Ghofur Anshori, Hukum dan Praktik Perwakafan di Indonesia, h. 14
} 
kondusif untuk terlaksananya praktek perwakafan secara baik. Tetapi dalam realitasnya, kondisi ideal dimaksud belum terlaksana hingga saat ini.

Muhammadiyah adalah sebuah persyarikatan atau organisasi Islam yang lahir di Yogyakarta, pada tanggal 8 Dzulhiijah 1330 Hijriyah atau 18 Nopember 1912 M. Pendiri utamanya adalah K.H A. Dahlan. Pasal 2 Anggaran Dasar Muhammadiyah secara singkat merumuskan "Muhammadiyah berasaskan Islam". Sedangkan maksud dan tujuan Muhammadiyah terdapat dalam Pasal 6 Anggaran Dasar Muhammadiyah, yaitu "Menegakkan dan menjunjung tinggi agama Islam sehingga terwujud masyarakat Islam yang sebesar-besarnya"

Dalam rangka untuk mencapai maksud dan tujuan di atas, Pasal 3 Anggaran Rumah Tangga Muhammadiyah menyebutkan sebanyak 14 butir tentang usaha yang dilakukannya, di antara 14 butir usaha tersebut, masalah wakaf secara eksplisit tercantum dalam angka 3, yang berbunyi "Meningkatkan semangat ibadah, jihad, zakat, infak, wakaf, shadaqah, hibah, dan amal shalih lainnya". Sekalipun demikian usaha di bidang lainnya juga terkait erat dengan masalah wakaf ini, misalnya usaha di bidang pendidikan, ilmu pengetahuan dan teknologi, kesehatan dan sosial. Sejak berdirinya, kegiatan Muhammadiyah hampir tidak terpisahkan dari urusan perwakafan tanah, struktur organisasinya pun terdapat satu bagian khusus yang mengurus masalah wakaf, yaitu Majelis Wakaf dan Zakat, Infak, Shadaqah (ZIS).

Untuk mewujudkan cita-cita dari tujuan perwakafan, maka Persyarikatan Muhammadiyah punya peranan dalam mengatasi problem yang terjadi serta memelihara, mengelola, memanfaatkan, dan berusaha mengembangkan wakaf aset tanah sebagai sarana untuk pengembangan keagamaan, pendidikan, ekonomi dan kewirausahaan serta kesejahteraan sosial dan kebudayaan.

\section{B. Metode Penelitian.}

Jenis penelitian penulis gunakan adalah penelitian lapangan (field research). Dari aspek sifat, penelitian ini akan menguji teori dari suatu obyek dan bagaimana realita yang ada dilapangan, maka aspek penelitian kualitatif juga diakomodir. Lokasi penelitian ini di Wilayah dan Daerah Persyarikatan Muhammadiyah yang ada di Sulawesi Selatan, hal mana fokus penelitian mengenai problematika Wakaf 
Aset tanah Persyarikatan Muhammadiyah di Sulawesi Selatan. Agar hasil penelitian ini dapat menemukan pemahaman subtantif, komprehensif dan holistik, maka pendekatan dalam penelitian ini sebagai berikut: a). Pendekatan historis; b). Pendekatan sosiologis; c). Pendekatan Teologis-Normatif; d). Pendekatan legal formal (yuridis). Dengan menggunakan teknik pengumpulan data; Interview dan dokumentasi.

\section{Hasil Penelitian Dan Pembahasan}

Di Indonesia sampai sekarang terdapat berbagai peraturan mengatur perwakafan tanah milik. Seperti dimuat dalam buku Himpunan Peraturan Perundang-undangan Perwakafan Tanah yang diterbitkan oleh DepartemenAgama RI, maka dapat dilakukan inventarisasi sebagai berikut:

- Undang-Undang No. 5 Tahun 1960 tanggal 24 September 1960 tentang Peraturan Dasar Pokok-Pokok Agraria.

- Peraturan Pemerintah No. 28 Tahun 1977 tanggal 17 Mei 1977 tentang Perwakafan Tanah Milik

- Instruksi Presiden (Inpres) No. 1 Tahun 1991 Tentang Kompilasi Hukum Islam.

- Undang-Undang No. 41 Tahun 2004 tentang Wakaf.

- Peraturan Pemerintah No. 42 Tahun 2006 tentang Pelaksanaan UndangUndang No. 41 Tahun 2004 tentang Wakaf. ${ }^{8}$

\section{Problematika Perwakafan di Persyarikatan Muhammadiyah Sulawesi}

\section{Selatan.}

Pada bagian ini, penulis membuat suatu analisa berdasarkan data yang telah penulis temui di lapangan. Adapun beberapa problem perwakafan yang penulis temukan sebagai berikut: Kurangnya pemahaman dan kepedulian terhadap wakaf; Banyaknya tanah wakaf yang belum bersertifikat; Pengelolaan manajemen

${ }^{8}$ Al-Alabij, Adijani. Perwakafan Tanah Di Indonesia dalam Teori dan Praktik, Jakarta: Rajawali Pers, 1973, h. 26 
setengah hati; SDM pengelolaan wakaf yang belum profesional; Objek wakaf dan komitmen nāẓir; lemahnya sistem control. ${ }^{9}$

Pengawasan adalah hal yang mutlak dilakukan. Beberapa dekade perwakafan di persyarikatan kurang mendapat pengawasan yang serius. Akibatnya cukup banyak tanah wakaf yang terlantar bahkan ada sebagian harta wakaf yang hilang. Olehnya itu sebuah lembaga wakaf harus bersedia untuk di audit. Setidaknya ada dua bentuk pengawasan yan sangat penting yaitu pengawasan masyarakat setempat dan pengawasan pemerintah yang berkompeten terhadap pengelolaan wakaf sebenarnya.

Jumlah tanah wakaf strategis dan kontroversi pengalihan wakaf untuk tujuan produktif. Saat ini tanah, perkebunan, sawah, ladang dan lain-lain yang diwakafkan ternyata banyak yang mempunyai nilai ekonomis yang minim. Letak yang tidak ekonomis bisa ditinjau dari beberapa aspek:

a. Lokasi tanah. Letak tanah yang jauh dari pusat-pusat perekonomian sangat mempengaruhi nilai tanahnya. Hal yang menjadi kendalanya adalah faktor transportasi, baik dalam proses-proses pengolahan maupun pengambilan hasilhasil tanah tersebut.

b. Kondisi tanah. Tanah yang gersang atau tidak subur jelas tidak menguntungkan secara ekonomi.

c. Kemampuan pengelolaan tanah yang minim. Di samping karena faktor letak tanah yang tidak strategis secara ekonomi dan kondisi tanah yang gersang, hambatan yang cukup mencolok adalah kemampuan SDM dari pengelola wakaf yang belum profesional dalam mengelola tanah wakaf. ${ }^{10}$

Penanganan wakaf di lingkungan warga Muhammadiyah sangat dipengaruhi oleh pemahaman mereka tentang wakaf. Penulis mengamati dan menemukan beberapa akar masalah secara internal yang menyebabkan sebagian besar program tidak terlaksana secara maksimal antara lain;

${ }^{9}$ A. Syarifuddin. Ketua Majelis Wakaf dan Kehartabendaan PWM Sulawesi Selatan Periode 2015-2020, Wawancara Tanggal 25 September 2016.

${ }^{10}$ Tim Depag. RI., Panduan Pemberdayaan Tanah Wakaf Produktif Strategis di Indonesia, Jakarta: Direktorat Pemberdayaan Wakaf Direktorat Jenderal Bimbingan Masyarakat Islam, 2007, h. 69 
- Hal yang berhubungan dengan sumber daya manusia:

1) Sebahagian pimpinan malas meningkatkan kemampuan intelektual dan skillnya terkait program inti majelis.

2) Terbatasnya waktu yang disediakan para pengurus atau pimpinan untuk aktif.

3) Adanya indikasi penurunan gairah ber-Muhammadiyah, seolah-olah mulai kehilangan visi dan misinya.

- Hal-hal yang berhubungan dengan sumber dana;

4) Untuk mengurus aset wakaf diperlukan biaya operasioanl yang cukup besar, sedangkan dana operasional majelis sangat terbatas.

5) Di samping biaya operasional dibutuhkan juga biaya-biaya resmi yang sudah ditentukan oleh instansi terkait.

- Hal yang berhubungan dengan pengamanan aset, kurangnya kepedulian pimpinan pada semua tingkatan untuk mengamankan dan memanfaatkan aset-aset Persyarikatan.

\section{Upaya Persyarikatan Muhammadiyah dalam Menyelesaikan Problematika Aset Perwakafan.}

Efektivitas pengelolaan harta tanah wakaf, pengelolaan ditinjau dari segi konsep adalah merupakan serangkaian kegiatan yang meliputi; Perencanaan; Pemanfaatan; Pengembangan; Pelestarian/pemeliharaan; Pengawasan; Penegakan hukum.

1) Perencanaan pengelolaan harta tanah wakaf.

Perencanaan pengelolaan harta tanah wakaf harus dilakukan secara cermat, khususnya bagi nāżir yang ditugasi untuk mengelola terhadap harta tanah wakaf. Adapun dalam kegiatan perencanaan pengelolaan harta tanah wakaf harus dilakukan dengan;

a) Pengelolaan harta tanah wakaf harus berdasarkan visi dan misi yang jelas. 
b) Melakukan pendataan terhadap harta tanah wakaf Persyarikatan Muhammadiyah yang meliputi tentang: Pengelolaan berdasarkan prinsip syari'ah dan pengelolaan dilakukan secara produktivitas ekonomi. ${ }^{11}$

Harta tanah wakaf yang mempunyai nilai dan manfaat ekonomi harus dikelola secara produktif dengan membangun Islamic Business Center, Hotel Syariah, Toko dan Ruko serta Restoran Kuliner.

2) Pemanfaatan harta tanah wakaf.

Dilihat dari segi pemanfaatan dan pengelolaan terhadap 222 lokasi wakaf aset tanah yang berada pada 19 Kabupaten/Kota yang ada di Sulawesi Selatan yang dilakukan oleh nāżir berdasarkan hasil penelitian penulis, sebagai berikut:

a) 57 lokasi digunakan untuk masjid.

b) 3 lokasi digunakan untuk musholla/tempat ibadah.

c) 81 lokasi digunakan untuk tempat pendidikan.

d) 15 lokasi digunakan untuk kegiatan sosial.

e) 9 lokasi digunakan untuk kantor.

f) 15 lokasi digunakan untuk pertanian.

g) 10 lokasi digunakan untuk perkebuna.

h) 1 lokasi digunakan untuk empang (perikanan).

i) 4 lokasi digunakan untuk rumah sewa/RUKO/KIOS.

j) 1 lokasi digunakan untuk rumah tinggal.

k) 2 lokasi digunakan untuk lapangan/sarana olahraga.

1) 34 lokasi yang masih terlantar dan belum jelas penggunaan dan pemanfaatannya. $^{12}$

3) Asas-asas pengelolaan harta tanah wakaf.

Pengelolaan pemanfaatan harta tanah wakaf yang berorientasi kepada pengembangan nilai produktivitas ekonomi guna peningkatan kesejahteraan

${ }^{11}$ Laporan Majelis Wakaf dan Kehartabendaan Pimpinan Wilayah Muhammadiyah Sulawesi Selatan 2015 - 2020, tanggal 28 Agustus 2016.

${ }^{12}$ A. Syarifuddin. Wawancara Tanggal 25 September 2016. 
umum, maka secara tehnis pengelolaan wakaf ini perlu diterapkan beberapa asas pengelolaan sebagai landasan. ${ }^{13}$

a) Asas manfaat.

Berdasarkan keyakinan religius bahwa berwakaf memiliki suatu nilai manfaat yang bersifat abadi yang pahalanya mengalir terus menerus selama benda wakaf tersebut dapat bermanfaat yaitu;

- Dapat dimanfaatkan oleh orang banyak. Contoh mewakafkan tanah untuk gedung sekolah, dimana gedung sekolah tersebut dapat dimanfaatkan oleh masyarakat sebagai sarana penyelenggaraan pendidikan.

- Dapat memberikan nilai manfaat yang lebih nyata sesuai dengan tujuan dan fungsi wakaf yang telah ditentukan oleh wakif, bahwa harta tanah wakaf yang telah diwakafkan tersebut sungguh-sungguh memberikan manfaat kepada orang lain, sehingga wakif merasa ada kepuasan secara batiniah.

- Dapat memberikan nilai manfaat secara immaterial yang lebih besar dari pada nilai materiilnya yaitu berupa pahala yang tak terhingga besarnya dan tak terbatas waktunya yang akan diperoleh oleh Wakif, selama harta tanah wakaf masih tetap dikelola dan dapat dimanfaatkan.

- Tidak menimbulkan keburukan (mudharat) baik bagi masyarakat banyak maupun bagi wakif sendiri.

b) Asas pertanggungjawaban.

Pelaksanaan pengelolaan harta benda wakaf mutlak diperlukan adanya pertanggungjawaban. Perwakafan di dalamnya mengandung aspek ibadah murni Ilahiyah dan aspek ibadah sosial insaniyah, oleh karenanya pengelolaan harta tanah wakaf harus dapat dipertanggungjawabkan, yang antara lain adalah: Tanggungjawab religius kepada Allah swt.; Tanggungjawab kelembagaan. Tanggungjawab hukum; Tanggungjawab sosial; Tanggungjawab moral.; Tanggungjawab intelektual.

\footnotetext{
${ }^{13}$ Abdul Manan, Hukum Wakaf Dalam Paradigma baru di Indonesia, No.255.Jakarta: Varia Peradilan, 2007, h. 50
} 
Nāzָir dalam melaksanakan pengelolaan pemanfaatan harta tanah wakaf sangat diperlukan adanya pengetahuan, kemampuan, dan ketrampilan yang memadai.

c) Asas profesionalitas.

Tugas $n \bar{a} z ָ i r$ untuk pengelolaan pemanfaatan harta wakaf merupakan bidang yang paling komplek, karena yang dapat menentukan suatu harta tanah wakaf itu dapat bermanfaat dengan sebaik-baiknya atau tidak, pengelolaan itu dapat memenuhi keinginan sesuai harapan atau tidak adalah sangat bergantung pada pengelolaannya oleh nāzir. Maka manajemen pengelolaan pemanfaatan harta tanah wakaf itu harus dilakukan dengan secara baik dan benar agar dapat menghasilkan manfaat yang sebasar-besarnya untuk kepentingan masyarakat.

4) Prinsip-prinsip pengelolaan harta tanah wakaf

Manajemen pengelolaan harta benda wakaf dalam rangka mewujudkan suatu kesejahteraan umum harus berdasarkan pada prinsip-prinsip pengelolaan yang baik. Di dalam pelaksanaan pengelolaan harta tanah wakaf yang dilakukan oleh nāzi ir juga harus berpedoman kepada pinsip-prinsip manajemen pengelolaan harta tanah wakaf yang baik dan agar terhindar dari kemungkinan terjadinya berbagai bentuk penyimpangan.

Adapun beberapa prinsip pengelolaan yang baik antara lain adalah meliputi prinsip-prinsip; partisipasi, penegakan hukum, trasnparansi, responsif, orientasi kesepakatan, keadilan, efektifitas dan efisiensi, akuntabilitas, visi strategis. ${ }^{14}$

a) Prinsip partisipasi; Meskipun nāzîir itu yang diberi kewenangan penuh untuk mengelola harta benda wakaf maka di dalam pengambilan kebijakankebijakan yang mendasar sebaiknya melibatkan partisipasi masyarakat, misalnya dalam perencanaan penukaran atau penjualan terhadap harta tanah wakaf.

b) Prinsip penegakan hukum; Penegakan hukum merupakan suatu usaha untuk mewujudkan ide-ide tentang keadilan, kepastian hukum dan kemanfaatan sosial menjadi kenyataan.

\footnotetext{
${ }^{14}$ Trianto dan Titik Wulandari Tutik, Falsafah Negara dan Pendidikan Kewarganegaraan, Jakarta :Prestasi Pustaka Publisher, 2007, h. 326
} 
c) Prinsip penegakan hukum merupakan landasan yang tidak dapat dikesampingkan dalam pengelolaan harta benda wakaf, tidak terkecuali tanah wakaf.

d) Prinsip transparansi; Dalam hal ini seorang nāẓir yang secara formal diberikan tugas dan kewenangan penuh untuk mengelola harta benda wakaf harus bersikaf transparan atau terbuka, sehingga Wakif maupun masyarakat dapat mengetahui secara jelas tentang segala usaha dan tindakan yang dilakukan oleh nāzizir dalam rangka pengelolaan harta benda wakaf.

e) Prinsip responsif; nāżir dalam melakukan tugas dan kewenangan mengelola harta benda wakaf harus bersikaf responsif dalam arti nāzizir harus cepat tanggap terhadap peluang-peluang pengelolaan yang bersifat produktif.

f) Prinsip orientasi kesepakatan; Dalam lembaga wakaf kedudukan nāżir bukan sebagai pemilik harta benda wakaf, tetapi hanya diberi tugas dan kewenangan untuk mengelolanya, oleh karenanya dalam pengambilan keputusan harus berdasarkan atas musyawarah untuk memperoleh kesepakatan dari berbagai pihak yang terkait dengan harta benda wakaf.

g) Prinsip kesetaraan dan keadilan; Pemanfaatan hasil harta benda wakaf harus dilakukan secara adil, siapa yang berhak atas hasil pengelolaan dari harta benda wakaf itu. Pemanfaat terhadap harta benda wakaf sangat luas, antara lain untuk menunjang sarana peribadatan, pendidikan, kesehatan, membantu fakir miskin dan kepentingan umum yang lainnya, maka harus dilakukan secara proporsional.

h) Prinsip efektivitas dan efisiensi; Efektif dalam arti pengelolaan harta benda wakaf dapat digunakan untuk memenuhi kepentingan masyarakat yang seluas-luasnya. dari berbagai kelompok dan lapisan sosial. Mampu memberikan kesejahteraan yang sebesar-besarnya dari berbagai kelompok dan lapisan sosial. Efisiensi dalam arti pemanfaatan hasil pengelolaan harta benda wakaf dilakukan dengan jalan yang sebaik mungkin jangan sampai terjadi suatu pemborosan.

i) Prinsip akuntabilitas; Tugas dan kewenangan yang diberikan kepada nāzָir untuk mengelola harta benda wakaf harus dilakukan dengan penuh 
tanggungjawab dan dapat terkontrol, sehingga dapat menghindari kemungkinan adanya tindakan-tindakan penyimpangan.

j) Prinsip visi strategis; Dalam pengelolaan harta benda wakaf yang cukup besar, khususnya tanah wakaf yang begitu luas maka nāzirir harus memiliki rencana kedepan yang lebih jelas, sehingga harta benda wakaf yang dikelolanya itu dapat semakin berkembang. ${ }^{15}$

5) Pengembangan harta tanah wakaf

Dalam kegiatan pengelolaan harta tanah wakaf nāzir wajib melakukannya sesuai dengan tujuan, fungsi dan peruntukannya yang telah ditentukan dalam Akta Ikrar Wakaf (AIW). Pengelolaan pengembangan harta tanah wakaf oleh nāzir harus dilakukan secara produktif yang hasilnya dapat memberikan manfaat secara ekonomi, guna memajukan kesejahteraan umum.

Pengembangan harta tanah wakaf harus dilakukan secara produktif sesuai dengan potensi yang mungkin dapat dikembangkan, yang antara lain dapat dikembangkan sebagai tempat perindustrian, pasar swalayan, industri pertanian, penginapan dan sebagainya. Pengelolaan pengembangan terhadap harta tanah wakaf harus dilakukan secara optimal dan sungguh-sungguh sesuai dengan tujuan dan fungsi wakaf. Pemberdayaan terhadap harta tanah wakaf hasilnya sekaligus dapat mengarah kepada pengembangan dalam pemanfaatan, serta dapat memperbesar jumlah modal. Pengembangan modal pengelolaan harta tanah wakaf secara langsung akan menjaga kelestarian harta tanah wakaf.

6) Pemeliharaan Harta Tanah Wakaf.

Kegiatan pengelolaan pemeliharaan harta tanah wakaf sehingga eksistensi harta tanah wakaf dapat berlangsung kelestariannya. Harta tanah wakaf yang berstatus sebagai hak milik dapat memberikan manfaat kepada masyarakat untuk selamanya, selama harta tanah wakaf itu masih memiliki potensi produktifitas ekonomi yang dapat dikelola secara efektif. Dalam pemeliharaan harta tanah wakaf nāżir memiliki tugas untuk menjaga keutuhannya, harta tanah wakaf jangan

\footnotetext{
${ }^{15}$ Riduan Syahrani.Rangkuman Intisari Ilmu Hukum, Bandung: Citra Aditya Bakti,1999, h. 192
} 
sampai beralih status kepemilikannya atau dialihkan kepemilikannya menjadi hak milik pribadi pihak lain.

Berdasarkan ketentuan pasal 40 Undang-Undang No. 41 Tahun 2004 Tentang Wakaf disebutkan bahwa harta benda wakaf yang sudah diwakafkan dilarang : Dijadikan jaminan ; Disita; Dihibahkan; Dijual; Diwariskan; Ditukar; Dialihkan dalam bentuk pengalihan hak lainnya.

\section{Kendala-Kendala dan Solusi/Gagasan Atas Problem Yang Dihadapi Persyarikatan Muhammadiyah Dalam Perwakafan.}

a. Kendala-kendala yang dialami Persyarikatan.

Dalam usaha menangani pengamanan tanah-tanah wakaf di Persyarikatan Muhammadiyah Sulawesi Selatan tersebut sangat perlu dikemukakan tantangan dan kendala yang cukup besar, bahkan tidak sedikit yang berakhir menjadi medan konflik. Karena hal ini berhubungan dengan hak kepemilikan, maka sumber problemnya pun beragam di samping begitu kompleksnya permasalahan yang mempengaruhinya. Sumber kendala yang terbesar adalah berasal dari kalangan internal, yakni warga persyarikatan di samping dari pihak luar terutama untuk aset wakaf yang selama ini menganggur. ${ }^{16}$

Beradasarkan hasil wawancara penulis secara langsung dilapangan, akan diuraikan beberapa persoalan yang dirasakan sebagai kendala dalam pengamanan wakaf aset tanah Persyarikatan Muhammadiyah di Sulawesi Selatan sebagai berikut; Letak lokasi wakaf yang jauh dari pemukiman; Rendahnya rasa memiliki (sense of belonging) pengurus dan warga Muhammadiyah terhadap aset wakaf.

Ada beberapa kejadian untuk membuktikan asumsi ini adalah sebagai berikut;

1) Penempatan pengurus wakaf dan kehartabendaan utamanya di tingkat Pimpinan Daerah Muhammadiyah (PDM) hanya sebatas pada mengisi kekosongan struktur organisasi.

\footnotetext{
${ }^{16}$ H. Muhammad Alwi Uddin. Wakil Ketua dan Koordinator Majelis Wakaf dan Kehartabendaan PWM Sulawesi Selatan Periode 2015-2020, Wawancara Tanggal 26 September 2016.
} 
2) Disharmonisasi antara pengurus Amal Usaha Muhammadiyah (AUM) dan pimpinan Daerah Muhammadiyah (PDM) berkaitan dengan upaya pengamanan aset wakaf terutama pada usaha penerbitan sertifikat lahan yang bersangkutan.

3) Bagi Pimpinan Daerah muhammadiyah (PDM) yang tidak memiliki Amal Usaha Muhammadiyah (AUM) di daerahnya, hampir dipastikan bahwa di daerah tersebut belum ada lahan wakaf yang telah terbit sertifikatnya atas nama Persyarikatan.

4) Pada setiap pergantian kepengurusan Majelis Wakaf dan Kehartabendaan di tingkat Pimpinan Daerah Muhammadiyah (PDM) dari periode ke periode, informasi dan database wakaf tidak di arsipkan dengan benar.

5) Terdapat banyak kasus kehilangan aset wakaf terutama di daerah-daerah karena tidak ditemukannya data atau keterangan tertulis yang menerangkan bahwa ada Wakif yang mewakafkan lahannya ke Muhammadiyah, apalagi saksi hidup tidak ada di tempat dengan berbagai faktor.

Seperti sudah dikemukakan di atas bahwa salah satu akibat dari ketidakjelasan status tanah wakaf, maka akan sangat memungkinkan timbulnya persengketaan baik antara wakif dengan Persyarikatan Muhammadiyah sebagai nāzì ataupun antara keluarga wakif dengan nāzir.

Berdasarkan hasil penelitian yang telah penulis lakukan dapat disimpulkan sebab yang menimbulkan terjadinya sengketa yaitu :

a) Akibat adanya perubahan status, misalnya menjadi tanah milik pribadi, dengan dalih hibah dari keluarga wakif.

b) Setelah wakif meninggal dunia, sebagian ahli warisnya menolak untuk mengakui bahwa tanah tersebut adalah tanah wakaf. Hal ini berkaitan dengan wakaf "Muallaq" atau wakaf dengan wasiat (wakaf yang ditangguhkan), suatu wakaf yang ikrarnya diucapkan pada saat wakif masih hidup tetapi pelaksanaan wakaf itu sendiri akan dilakukan setelah si wakif meninggal dunia. 
c) Ahli waris tidak mengetahui adanya perwakafan yang dilakukan oleh orang tuanya, karena tidak ada tanda bukti yang kuat seperti tanda bukti yang tertulis, sehingga oleh ahli waris tanah wakaf tersebut dijual.

d) Terjadinya peralihan fungsi atas tanah wakaf yang pada mulanyadiperuntukkan sebagai masjid tapi dimanfaatkan untuk kepentingan lain,walaupun sebelumnya $n \bar{a} z \bar{i}$ ir sudah memberitahukan peralihan fungsi tersebutkepada wakif tapi pelaksanaannya tidak sesuai dengan yang disebutkan dalam Pasal 36 Undang-Undang No. 41 Tahun 2004 tentang wakaf :

"Dalam hal harta benda wakaf ditukar atau diubah peruntukannya, $n \bar{a} z$ ir melalui PPAIW mendaftarkan kembali kepada instansi yang berwenang dan Badan Wakaf Indonesia atas harta benda wakaf yang ditukar atau diubah peruntukannya itu sesuai dengan ketentuan yang berlaku dalam tata cara pendaftaran harta benda wakaf".

Mengenai pihak-pihak yang terlibat dalam sengketa yang biasanya terjadi dalam suatu masyarakat yaitu ahli waris dengan nāziir yang sengaja melibatkan diri untuk kepentingan pribadi. Dalam keadaannya seperti ini penyelesaian melalui usaha-usaha musyawarah menjadi tidak memungkinkan lagi untuk menyelesaikannya, karena adanya konflik kepentingan satu sama lain.

e) Masih adanya tanah wakaf yang belum bersertifikat dengan berbagai masalah sebagai berikut;

- Kurangnya tenaga ahli yang memiliki kemampuan dan memiliki banyak kesempatan untuk mengurusi dan mengelola secara serius kekayaan Persyarikatan, khususnya mengenai tanah wakaf. Terlebih lagi personalia pimpinan yang duduk sebagai Pimpinan Majelis dan Kehartabendaan di beberapa tingkat pimpinan daerah dan cabang tertentu kebanyakan terdiri dari orang-orang penting dan sibuk, serta merangkap sebagai pejabat/ pegawai pemeritahan atau kantor swasta, sehingga intensitas untuk mengurus tanah wakaf tidak fokus.

- Adanya tuntutan dari para ahli waris bahwa tanah yang telah diwakafkan oleh orang tuanya (wakif) tanpa persetujuan para ahli waris, dalam hal ini 
ahli waris dari si wakif merasa keberatan dan mengajukan pembatalan wakaf tersebut sehingga menghambat legalitas (sertifikasi) tanah wakaf.

- Adanya tuntutan dari pihak keluarga sebagai penyewa dari tanah yang diwakafkan oleh wakif, yang merasa bahwa tanah itu telah menjadi miliknya.

- Proses sistem birokrasi pengurusan tanah wakaf terutama yang bermasalah cenderung memakan waktu lama dan membutuhkan perhatian khusus, ditambah lagi kurangnya tenaga yang memiliki kepedulian sehingga berakibat pada berlarut-larutnya proses penyelesaian persoalan wakaf yang terjadi.

- Dalam pengelolaan tanah wakaf tidak mempunyai hak-hak yang jelas, baik penghasilan maupun imbalan lainnya.

- Sebagian besar menganggap pekerjaan nāzịir tanah wakaf bukan pekerjaan utama/pokok, tetapi lebih merupakan pekerjaan sampingan dan memerlukan keikhlasan. Artinya pekerjaan sebagai nāzị wakaf baru dilaksanakan jika terdapat waktu luang, tidak mengganggu pekerjaan utama dan pada hari-hari libur. Dalam pekerjaan ini mereka tidak mendapat imbalan apa-apa dari pekerjaannya sebagai nāżir.

- Status tanah wakaf tersebut tidak memiliki kekuatan hukum. Hal ini dapat terjadi karena pada umumnya status wakaf dari sebidang tanah hanya disampaikan secara lisan tanpa ada dokumen tertulis. Padahal ahli waris, anak atau cucu dari orang yang mewakafkan mungkin tidak tahu ada ucapan seperti itu. Apatah lagi kalau yang berwakaf sudah meninggal.

- Kendala dari segi kesadaran masyarakat. Kurangnya kesadaran masyarakat untuk melakukan kegiatan pengelolaan perwakafan secara transparan atau terbuka yang bisa mendatangkan masukan dari masyarakat secara luas. Dari pihak Kementerian Agama juga kekurangan tenaga penyuluh ke masalah-masalah yang berkaitan dengan masalah perwakafan.

\section{Solusi/Gagasan Atas Problem Wakaf yang Dihadapi Persyarikatan.}

Sebagai organisasi keagamaan yang sudah cukup tua dari segi usia dan sudah matang dari segi pengalaman, maka seyogyanya pun harus sudah cukup 
amanah dalam mengemban amanah dan kepercayaan. Olehnya itu berangkat dari permasalahan di atas yang betul-betul merupakan problem terhadap akselerasi tugas dan fungsi Majelis Wakaf dan Kehartabendaan Pimpinan Wilayah Muhammadiyah Sulawesi Selatan, maka dari itu penulis mencoba menawarkan beberapa solusi dan gagasan serta langkah strategis untuk di implementasikan yang antara lain sebagai berikut:

a. Pemanfaatan wakaf aset berupa tanah yang masih kosong dan cenderung terabaikan untuk dikembangkan dan diberdayagunakan secara produktif untuk kemaslahatan ummat.

b. Menawarkan kepada pihak lain dalam bentuk sewa lahan. Hal ini memungkinkan untuk dilakukan, karena tidak sedikit orang atau perusahaan yang ingin mengembangkan usahanya tapi terkendala pada ketersediaan lahan. Terutama untuk usaha yang bergerak pada sektor peternakan, industri yang berskala rumah tangga dan sektor perkebunan. Hal seperti ini dapat dilakukakan kerjasama yang tentunya menganut asas manfaat dan terjaminnya kepastian hukum di dalamnya.

c. Melakukan penanaman pohon yang bernilai ekonomis. Hal ini dapat dilakukan sebagai salah satu peran untuk ikut serta dalam membantu program pemerintah menggalakkan penghijauan demi menjaga kelestarian lingkungan. Kegiatan ini sangat bermanfaat untuk dilakukan, karena di samping tidak membutuhkan alokasi anggaran yang cukup besar dan bahkan bibitnya bisa diperoleh secara gratis.

d. Pola penerapan manajemen yang sangat sederhana dengan potensi ekonomi dan ekologi yang dikembangkan dapat ditumbuhkembangkan secara berkesinambungan.

e. Setiap saat melakukan pendataan (inventarisasi) dan arbitrase harta benda, khususnya aset wakaf berupa tanah yang diperoleh dari wakif serta mengintensifkan pelaksanaan penerbitan dan pengelolaan sertfikasi tanah wakaf Persyarikatan.

f. Melakukan verifikasi faktual terhadap aset tanah wakaf yang tersebar di tingkat daerah dan cabang mencakup kepemilikan, luasnya maupun 
bangunannya serta pemanfaatannya. Hal ini dilakukan untuk kesinambungan dan ketertiban data administrasi data di lapangang pada tingkat PWM, PDM, PCM dan PRM dapat dipertanggungjawabkan kepemilikan dan keabsahannya secara hukum.

g. Melakukan pelatihan, bimbingan, tuntunan, panduan, pedoman tentang prosedur penerimaan dan pelaksanaan serta pemeliharaan harta tetap dan tidak tetap Persyarikatan Muhammadiyah.

h. Melakukan upaya pengamanan dan penguatan seluruh wakaf aset Persyarikatan yang masih tercatat atas nama perorangan, pengurus Muhammadiyah dan atau atas nama Pimpinan Muhammadiyah selaku nāzị, baik daerah maupun cabang untuk segera dilakukan balik nama menjadi untuk dan atas nama Persyarikatan Muhammadiyah yang berkedudukan di Yogyakarta dan Jakarta.

i. Perlu adanya kebijaksanaan dari pemerintah baik dari segi bantuan biaya sertifikasi tanah wakaf, juga dalam pengelolaan tanah-tanah wakaf, karena seandainya pemerintah mau mengelola harta-harta wakaf secara baik / maksimal, didanai, maka akan dapat meningkatkan ekonomi umat secara maksimal.

j. Mendorong secara lebih luas kepada masyarakat agar lebih peduli terhadap pentingnya harta wakaf di tengah kehidupan sosial kemasyarakatan. Melalui upaya sosialisasi wakaf diharapkan masyarakat semakin mengerti mengenai pentingnya pelaksanaan ibadah wakaf untuk kepentingan masyarakat banyak.

k. Penyelesaian suatu sengketa atas perwakafan dapat diselesaikan menurut ketentuan Pasal 62 UU No. 41 Tahun 2004 tentang Wakaf :

1) Penyelesaian sengketa perwakafan ditempuh melalui musyawarah untuk mencapai mufakat.

2) Apabila penyelesaian sengketa sebagaimana dimaksud pada Ayat (1) tidak berhasil, sengketa dapat diselesaikan melalui mediasi, arbitrase, atau pengadilan. 
Selanjutnya bagaimana caranya untuk menyelesaikan perselisihan tersebut supaya berfungsi sesuai dengan yang diinginkan, maka ada beberapa upaya hukum yang dilakukan, yaitu :

a. Mengusahakan dengan cara musyawarah secara terbuka dengan mengundang tokoh-tokoh masyarakat dan pihak KUA setempat.

b. Apabila dengan cara musyawarah masih juga tidak berhasil, maka penyelesaian sengketa dengan bantuan pihak ketiga (mediator) yang disepakati oleh para pihak yang bersengketa. Dalam hal mediasi tidak berhasil menyelesaikan sengketa, maka sengketa tersebut dapat dibawa kepada badan arbitrase syariah. Dalam hal badan arbitrase syariah tidak berhasil menyelesaikan sengketa, maka sengketa tersebut dapat dibawa ke Pengadilan Agama dan/atau Mahkamah Syari'ah.

c. Agar fungsi pemanfaatan dan pengelolaan tanah wakaf berhasil optimal, maka negara sebagai institusi yang mempunyai daya paksa dapat mengakomodir dan memberi tempat lembaga wakaf untuk berkembang.

d. Masyarakat khususnya umat Islam di Indonesia, dituntut berperan aktif dan berpartisipasi dalam mengangkat lembaga wakaf agar supaya sederajat dengan lembaga-lembaga sosial lain yang ada dan diatur oleh negara. 


\section{Penutup}

Setelah diuraikan Berdasarkan pembahasan yang telah dilakukan, maka kesimpulan problematika wakaf aset tanah Persyarikatan Muhammadiyah di Sulawesi Selatan, maka penulis dapat menarik beberapa kesimpulan sebagai berikut:

Pertama, Pemahaman dan kepedulian masyarakat sangat kurang. Sehingga dalam menyerahkan wakafnya hanya didasarkan pada kepercayaan semata. Terdapat pula diantaranya tanah wakaf yang tidak mempunyai bukti administratif yang menyulitkan untuk pengurusan penerbitan sertifikat wakaf. Sistem manajemen dan tenaga SDM yang lemah serta tidak profesional, sehingga pengelolaan tanah wakaf banyak yang kurang produktif dan tidak menghasilkan guna mensejahterahkan umat. Selain itu lemahnya sistem kontrol dan pengawasan yang berdampak pada penanganan tanah wakaf kurang terurusi dengan baik.

Kedua, Pimpinan Persyarikatan, khususnya Majelis Wakaf dan Kehartabendaan telah berupaya untuk melakukan pendataan yang tercatat di 18 Kabupaten/Kota wakaf aset tanah Persyarikatan Muhammadiyah di Sulawesi Selatan yang menempati 232 lokasi dari $951.998 \mathrm{M}^{2}$ yang dikuasai/dimiliki oleh Persyarikatan. Melakukan pengelolaan, pemanfaatan sesuai dengan peruntukannya yang berorientasi pada pengembangan nilai produktifitas ekonomi untuk kesejahteraan umat dengan prinsip dan asas-asas, pengembangan dan pemeliharaan harta wakaf aset tanah sesuai dengan ketentuan dan undang-undang wakaf. 


\section{DAFTAR PUSTAKA}

Al-Alabij, Adijani. Perwakafan Tanah Di Indonesia dalam Teori dan Praktik, Jakarta: Rajawali Pers, 1973.

Anshori, Abdul Ghofur. Hukum dan Praktik Perwakafan di Indonesia, Yogyakarta: Pilar Media, 2005.

Ali, Muhammad Daud. Sistem Perekonomian Islam, Zakat dan Wakaf, Cet. I; Jakarta: UIPress, 1988.

Departemen Agama RI, Salam Qur'an: Al Qur'anul Karim dan Terjemahan Edisi Keluarga,Bandung: Salamadani, 2009.

Kementerian Agama RI, "Paradigma Baru Wakaf di Indonesia. Jakarta: Direktorat Pemberdayaan Wakaf Direktorat Jenderal Bimbingan Masyarakat Islam, 2006.

."Pedoman Pengelolaan dan Pengembangan Wakaf'Jakarta: Direktorat Jenderal Bimbingan Islam dan Direktorat Jenderal Wakaf, 2006.

Manan, Abdul. Hukum Wakaf Dalam Paradigma baru di Indonesia, No.255.Jakarta: Varia Peradilan, 2007.

Praja, Juhaya S. Perwakafan di Indonesia:Sejarah, Pemikiran, Hukum dan Perkembangannya. Cet. 1; Bandung:Yayasan Tiara, 1995.

Riduan Syahrani.Rangkuman Intisari Ilmu Hukum, Bandung: Citra Aditya Bakti,1999.

Rofiq, Ahmad. Hukum Islam di Indonesia, Cet. 6; Jakarta: PT. Raja Grafindo Persada, 2003.

Trianto dan Titik Wulandari Tutik, Falsafah Negara dan Pendidikan Kewarganegaraan, Jakarta :Prestasi Pustaka Publisher, 2007.

Tim Depag. RI., Panduan Pemberdayaan Tanah Wakaf Produktif Strategis di Indonesia, Jakarta: Direktorat Pemberdayaan Wakaf Direktorat Jenderal Bimbingan Masyarakat Islam, 2007.

Undang-Undang No. 41 Tahun 2004 Tentang Wakaf.

Usman, Rachmadi.Hukum Perwakafan Di Indonesia. Cet. 1; Jakarta : Sinar Grafika, 2009.

Zein, Satria Efendi M. "Saksi dan Ikrar Dalam Wakaf", dalam Problematika Hukum Keluarga Islam Kontemporer Cet. 1; Jakarta: Fakultas Syari'ah dan Hukum UIN Jakarta dan Balitbang DEPAG RI, 2004. 


\section{Daftar Wawancara}

A. Syarifuddin. Ketua Majelis Wakaf dan Kehartabendaan PWM Sulawesi Selatan Periode 2015-2020, Wawancara Tanggal 25 September 2016.

Laporan Majelis Wakaf dan Kehartabendaan Pimpinan Wilayah Muhammadiyah Sulawesi Selatan 2015 - 2020, tanggal 28 Agustus 2016.

H. Muhammad Alwi Uddin. Wakil Ketua dan Koordinator Majelis Wakaf dan Kehartabendaan PWM Sulawesi Selatan Periode 2015-2020, Wawancara Tanggal 26 September 2016.

Pimpinan Wilayah Muhammadiyah Sulawesi Selatan, "Laporan Pimpinan Wilayah Muhammadiyah Sulawesi Selatan dalam Musyawarah Wilayah Ke-39 Muhammadiyah Sulawesi Selatan” di Kota Palopo 12-14 Rabiul Awwal 1437 H/24-26 Desember 2015 M 